\title{
Conceptualisation of Hotel Guest Experience Assessment Process and Electronic Words of Mouth
}

\author{
Han Chao ${ }^{1}$, Basri Rashid ${ }^{2 *}$ \\ ${ }^{1}$ Tourism Management, North Minzu University, China \\ ${ }^{2}$ School of Tourism, Hospitality and Event Management, Universiti Utara Malaysia, Malaysia
}

\begin{abstract}
The success of a hotel depends on the guests' interpretation and reviews of their visit experience. Guests who perceived their visit experience as worthiness and satisfactory would circulate their experience to their acquaintances. In today's information based era, their visit experience can be widely circulated through electronic word of mouth (ewom) such as the social media. This paper aims to construct a research framework to study hotel guests experience responses as the result from their encounters with the hotel's products and services during their stay. Unforgettable encounters would influence the guests' future behaviour, starting with their commitment and eventually translated into reaction in the forms of electronic word of mouth responses. Methodically, an exhaustive review of the literature was carried out to establish a theoretical underpinning of hotel guests experience assessment process and their future responses. Perceived value and satisfaction are deemed as important measurements in the initial stage of the hotel guest visit experience outcomes. In line with the current information technology trends, the guests are expected to use electronic word of mouth to disseminate their visit outcomes. Academically, the study framework reduces the gaps related to the formulation of research constructs for hotel visit experience assessment. It is assertive that this paper would be practically beneficial to hotel operators or relevant stakeholders in order to gain a comprehensive understanding about hotel guests' visit experience responses and their future behaviour, including the electronic wordof-mouth response.
\end{abstract}

Keywords: Commitment, electric word-of-mouth, hotel, perceived value, post visit responses, satisfaction.

\section{INTRODUCTION}

When hotel guests visit a hotel, they are exposed to the various products and services at the hotel. The hotel guests' experience then is determined whether these products and services can meet their needs and wants. Ideally, the overall experience is noted as the performance of the hotel staff, products, services, and hotel facilities, as well as the benefit gained by the guests from the performance. The outcome of this experience shall then influence their future responses.

Past research indicated that the customer experience assessment is a very complex process, and it is difficult to measure directly. However, the literature points out that perceived value would be a realistic component to initially measure customer responses. In this paper, it is asserted that perceived value can help the hotel analyse the overall experience of the hotel's guests and understand their behavior. Therefore, by understanding the guests' perceived value, hotels can provide a better experience to their

\footnotetext{
${ }^{*}$ Correspondence address:

Basri Rashid

Email : basri@uum.edu.my

Address : School of Tourism, Hospitality and Event Management, Universiti Utara Malaysia, Malaysia, 06010
}

guests by offering products, facilities, and services that meet their requirements.

Another important result of the visit experience is satisfaction. Past studies pointed out that perceived value is the antecedent of satisfaction. Thus in this paper, it is postulated that perceived value will influence satisfaction. In addition, customers frequently disseminate their experience to others through various mediums, and with the advancement of communication technology, social media is a common and convenient method of disseminating information. Those who are committed to this type of media would update their information regularly. Hence, the whole picture of guest experience process can be depicted through the relationship among perceived value, satisfaction, commitment, and electronic word-of-mouth. In other words it is foreseen that perceived value influences satisfaction and commitment in which ultimately affect hotel guests' electric word-of-mouth.

\section{HOTEL GUEST'S EXPERIENCE}

This segment reviews past studies that are related to customer post-consumption experience and relate them to the hotel guests' experience responses. Discussions are focused on the relevant constructs that lead to the formation of a research framework. Specifically, this section reviews related variables namely; 
perceived value, satisfaction, commitment and electronic word-of-mouth, and the relationship among all these variables.

\section{A. Perceived Value}

A hotel can provide customers with acceptable products or services only if the needs and wants of the customers are fulfilled. The emphasis should be on the value delivery during the interaction between the customer and the operator [1]. As a result, the customers would feel they have received the value from what they have spent on. Past studies pointed out that perceived value plays an essential role to reflect the hotel guest's comprehensive experience and hotel guest behavior.

Perceived value is defined as the consumer's overall assessment of the utility of a product based on perceptions of what is received and what is given [2]. It translates perception as a whole unit, rather than just an emotion. This Perceived value definition extended as the customer's overall assessment of the net worth, which is derived from the customer's assessment of benefit they gained in relation to their participation with the services, products, and activities that also consume time, money, and energy [3]. Similarly, perceived value is a comparison of benefits, costs, and usually occur during the purchase of related products or services [4]. In addition, perceived value can be seen as the difference between the total benefits and the total costs experienced by hotel guests [5]. The total benefits are a combination of the corresponding attributes, for example, physical attributes and service attributes [6]. The total costs include monetary provisions [7] and nonmonetary provisions [8].

However, researchers have disputes about the concepts of one-dimensional and multidimensional of perceived value. The first proposed the concept of price-perceived value one-dimensional, which is based on the monetary value dimension [2]. The onedimensional is also used to measure the customer's overall value [9]. However, this measurement cannot reflect the viewpoint, which many researchers asserted perceived value is the trade-off between benefits and sacrifices, and it caused the one dimensional evaluation to receive less attention in the research community. Since every person has its own personality and characteristics, which results in various perceptions of customers towards the hospitality of each hotel, it is not adequate to explain the perceived value using a one-dimensional (monetary value) approach [10].

Numerous other researchers are devoted towards the study of multi-dimensional aspects of perceived value. For example, four dimensions of perceived value: emotional value; social value; functional value (monetary); functional value (quality), as a more comprehensive measurement of perceived value [11]. On the other hand, perceived value is divided into five dimensions: quality, emotional response, monetary price, behavioral price, and reputation [12]. The four dimensions of perceived value represent the views of PERVAL and the five dimensions of perceived value represent the views of SER-PERVAL, the difference between them is that four dimensions of perceived value divided monetary value into two dimensions: monetary price and behavioral price, and suggested reputation take the place of social value. Overall, the validity and reliability of multidimensional perceived value have been confirmed [9], thus the multiple dimensional evaluation method is considered better than the single-dimensional evaluation method to explain the perceived value.

In order to attract new hotel guest or maintain the relationship with customers, hotel operators need to predict the guests' future behavior based on perceived value [1]. In this case, the guest's perceived value is based on the consumption of relevant products and facilities of the hotel that may influence guests' visit outcomes, namely satisfaction, commitment, and E-WOM. This statement is reasonable because many researchers have proved that customer perceived value can affect customer satisfaction and commitment $[13,14,15]$. Furthermore, customer experience and satisfaction can be used as a precedent for their future intentions $[16,17,18]$.

\section{B. Satisfaction}

The main difference between perceived value and satisfaction is their occurrence time [19]. Perceived value can occur at a different stage of a purchase. However, satisfaction occurs at the post-stage of purchase. Hence based on past studies, it is asserted that satisfaction can be an outcome of perceived value $[20,21,22]$.

Researchers have applied customer satisfaction theory to various service industries to investigate the applicability of customer satisfaction, including the hotel industry [23], the foodservice industry [24], and the tourism 
industry [25]. Customer satisfaction defined as a result of high expectation towards the service provided [26]. This classical definition is based on the expectancy-disconfirmation theory (EDT), which has attracted the attention of many scholars and dubbed as the most widely used theory of customer satisfaction [26,27].

However, this theory has been challenged in various studies. Some researchers pointed out that there are some deficiencies in both the theoretical and operational aspects of the EDT. For example, excessive information might increase customers' expectations towards the service, compared to the expectation they had before [28]. When the hotel operator overstated advertising claims, the customer's expectations will be high. As a result, the customer will feel dissatisfied even with a high-quality service or product.

The measurements of satisfaction by expectancy-disconfirmation paradigm may only materialize if the consumers have expectations for related products and services before consumption [29]. In fact, it would be inappropriate to evaluate the hotel guest's satisfaction because whenever the customer is relatively unknown or unfamiliar with relative products and services of the hotel, they would have no pre-expectation of any such services.

Six alternative models were used to compare and examine the relative validity of these models to measure customers' satisfaction [19]. The models are performance only, importantperformance, importance minus performance, direct confirmation-disconfirmation, confirmation-disconfirmation weighted by importance, and performance minus predictive expectation. It was concluded that the performance model offers a better framework for measuring customer satisfaction. Various other studies confirmed the advantages of using a performance-only model to study satisfaction. Therefore, perceived performance is the best predictor of satisfaction when it is difficult to measure the expected value [19,30-33]. In addition, satisfaction can be regarded as the customer's attitude towards service providers and conceptualized as an overall outcome of judgment [15].

Numerous researchers pointed out that satisfaction has a direct positive impact on commitment $[34,35,36]$. The influence of satisfaction on commitments has created a tendency that the customer will recommend the service provider to other consumers or create a preference for the service provider on the next purchase.

\section{Commitment}

The importance of the relationship in the service marketing field has been confirmed by many scholars, and this is often based on the mutual commitments of buyers and sellers [37]. The key to maintaining this relationship is when the customer has achieved a valuable experience, and the seller has made every effort to maintain and develop this relationship between them and the customer [6]. The widely accepted definition of customer commitment by academics is that trading partners who are willing to maintain a lasting and important relationship [38,39]. Therefore, commitments are a kind of psychological emotion, which forms between two or more business partners. It also reflects the continuity of the business.

There is no unified recognition of the structural model of commitment. Some researchers pointed out that commitment is a multidimensional structure that includes affective and calculative or continuance commitment $[40,41]$. Affective commitment is a combination of emotions that reflects the consumer's sense of participation and belonging to the service $[40,42]$. When continuance commitment occurs, consumers are forced to commit to the sales of organization because the termination of this bond may result in loss and sacrifice in business (economic or social sacrifice) [43].

In the marketing relationship, when the conversion cost is low, the consumers are given the freedom to choose many types of samples and items from the sales. However, when consumers are unfamiliar or neither purchased the product nor service, continuance commitment may not occur. Therefore, when commitment is primarily defined as affective commitment, it resolves as a better understanding of premises and thus a good analysis of emotional commitment [38]. Hence, many researchers suggest using a onedimensional structure to measure commitment in a social-business bond.

In the vast majority of commitment-related marketing research, affective commitment is the one-dimensional structure measurement of commitment [44]. Affective commitment occurs when there is a consumption relationship between consumers and organizations [45]. Customer commitment aims to maintain a good 
and reputable relationship with the organization, while affective commitment can represent the customer's commitment [46]. Affective commitment is rooted in identity, which represents the nature of the customer's assurance [47].

There is a positive relationship between the commitment of the organization and the future intention of consumers [38]. The positive effect of commitment on word-of-mouth was recognized by scholars $[48,49,50]$. The positive EWOM will only arise when satisfaction translates into a commitment because the commitment leads to the willingness of the marketer and the buyer to maintain the behavior of partnerships [23].

\section{Electronic Word-Of-Mouth}

In recent years, due to the advancement in communication technology, numerous social media are freely available. This electronic communication platform has resulted in the widespread of information. The user-generated related content is the basis of social media, resulting in the creation of the term "electronic word-of-mouth" (E-WOM) [51].

Generally, word-of-mouth (WOM) defined as an informal communication of consumers about specific products or services [52], which is regarded as one of the most important sources of information by customers. Electronic word-ofmouth (E-WOM) can be defined as all informal communications to consumers through webbased technologies. Nowadays, customers can post their thoughts, ideas, and feelings about products and services online by sending emails or writing articles on blogs [53]. The impact of EWOM towards decisions made by customers may be greater than the impact of traditional wordof-mouth. The E-WOM expands the customer's choice of collecting information about products and services from other customers. In other words, the electronic environment is an innovative and convenient place to collect the required information. Therefore, E-WOM plays an important role in purchasing today's consumption.

In the tourism industry, travelers are increasingly turning to E-WOM for support towards their traveling plans and travelingrelated decisions [54]. E-WOM influences tourists' visit intention and points out that EWOM provides travelers with more travel-related information and has a convincing influence on travelers' tour choices and behavior [55].
In the hotel industry, the relationship between E-WOM and consumers' online purchases seemed to be stronger than the tourism industry [56]. Positive online reviews improve the perception of hotels among potential consumers [57]. Moreover, the intangible nature of the experience intensifies the uncertainty of consumers, which motivates them to search for relevant information and increases their dependence on electronic wordof-mouth. The hotel guests showed significant interest in E-WOM [58]. Therefore, electronic word-of-mouth may greatly influence the hotel guest behaviour.

\section{RELATIONSHIP AMONG THE VARIABLES}

As deliberated in the preceding sections, this paper asserts that perceived value can be used in the overall assessment of the effectiveness of a product (or service) after the consumer experiences the process of related products and services. Satisfaction is presumed to be affected directly by perceived value. Nonetheless, perceived value is also one of the important factors affecting guests' commitment $[59,60]$. However, the literature also established the relationship between satisfaction and commitment, thus making satisfaction a mediator variable between perceived value and commitment $[38,44,61]$. Therefore, this paper proposes a research framework for the hotel guest experience assessment process, as depicted in Figure 1.

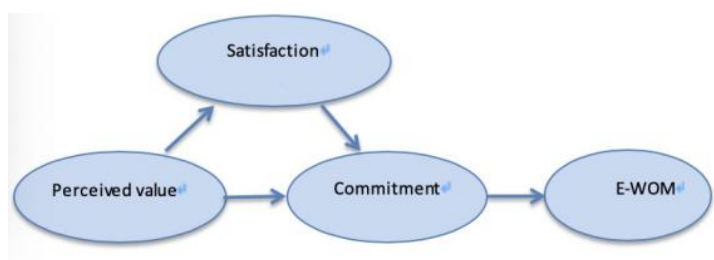

Figure 1. Research Framework

The framework shows that the variables under study are perceived value, satisfaction, commitment, and E-WOM. It examines the impact of hotel guests' perceived value on satisfaction and commitment. Commitment, in return, affects guests' E-WOM. In terms of classification, perceived value is an independent variable, while satisfaction can be seen as a moderator between perceived value and commitment. The effect of E-WOM can be measured directly and indirectly through the three variables; perceived value, satisfaction, and commitment. 


\section{CONCLUSION}

This paper suggests that customer experience is a result of a comprehensive post-consumption assessment of perceived value responses. This assessment method is deemed applicable to the hotel industry. At the initial stage, the guest experience evaluation, perceived value, and satisfaction that play a very important role to generate guests' commitment. Ultimately, the guests are expected to use electronic word of mouth to disseminate their visit outcomes. Theoretically, the framework reduces the gaps related to the formulation of research constructs for hotel visit experience assessment. Practically, the framework is beneficial to hotel operators or relevant stakeholders to gain a comprehensive understanding of hotel guests' visit experience responses and their future behavior, including the electronic word-of-mouth response. Nonetheless, the framework should be tested to confirm its robustness.

\section{REFERENCES}

[1] Tadeja, K. 2008. The influence of perceived value on customer loyalty in Slovenian hotel industry. Turizam 12, 12-15.

[2] Zeithaml, V. A. 1988. Consumer perceptions of price, quality, and value: a means-end model and synthesis of evidence. The Journal of Marketing, 2-22.

[3] Kim, Y. H., J. Duncan, and B. W. Chung. 2015. Involvement, satisfaction, perceived value, and revisit intention: A case study of a food festival. Journal of Culinary Science and Technology 13(2), 133-158.

[4] Pandža Bajs, I. 2015. Tourist perceived value, relationship to satisfaction, and behavioral intentions: The example of the Croatian tourist destination Dubrovnik. Journal of Travel Research 54(1), 122-134.

[5] Jamal, S. A., N. A. Othman, and N. M. N. Muhammad. 2011. Tourist perceived value in a community-based homestay visit: An investigation into the functional and experiential aspect of value. Journal of Vacation Marketing 17(1), 5-15.

[6] Monroe, K. B. 1990. Pricing: Making profitable decisions. McGraw-Hill. New York.

[7] Anderson, E. W., and M. W. Sullivan. 1993. The antecedents and consequences of customer satisfaction for firms. Marketing Science 12(2), 125-143.

[8] Cronin, J. J., M. K. Brady, R. R. Brand, R. Hightower Jr, and D. J. Shemwell. 1997. A cross-sectional test of the effect and conceptualization of service value. Journal of Services Marketing 11(6), 375-391.

[9] Petrick, J. F. 2004. The roles of quality, value, and satisfaction in predicting cruise passengers' behavioral intentions. Journal of Travel Research 42(4), 397-407.

[10] Raza, M. A., A. N. Siddiquei, H. M. Awan, and K. Bukhari. 2012. Relationship between service quality, perceived value, satisfaction and revisit intention in hotel industry. Interdisciplinary Journal of Contemporary Research in Business 4(8), 788-805.

[11] Sweeney, J. C., and G. N. Soutar. 2001. Consumer perceived value: The development of a multiple item scale. Journal of Retailing 77(2), 203-220.

[12] Petrick, J. F. 2002. Development of a multidimensional scale for measuring the perceived value of a service. Journal of Leisure Research 34(2), 119-134.

[13] Wang, Y., H. Po Lo, R. Chi, and Y. Yang. 2004. An integrated framework for customer value and customer-relationshipmanagement performance: a customerbased perspective from China. Managing Service Quality: An International Journal 14(2/3), 169-182.

[14] Dehghan, A. N., H. Alizadeh, and S. MirzaeiAlamouti. 2015. Exploring the customer perceived values as antecedent of purchase behavior. Serbian Journal of Management 10(2), 173-188.

[15] Lemon, K. N., and P. C. Verhoef. 2016. Understanding customer experience throughout the customer journey. Journal of Marketing 80(6), 69-96.

[16] Yüksel, A., and M. Rimmington. 1998. Customer-satisfaction measurement: Performance counts. Cornell Hotel and Restaurant Administration Quarterly 39(6), 60-70.

[17] Page Jr, T. J., and R. A. Spreng. 2002. Difference scores versus direct effects in service quality measurement. Journal of Service Research 4(3), 184-192.

[18] Rashid, B. 2013. Post Visit Assessment: The influence of consumption emotion on tourist future intention. Journal of Business and Management 9(3), 39-45

[19] Woodruff, R. B. 1997. Customer value: the next source for competitive advantage. Journal of the Academy of Marketing Science 25(2), 139. 
[20] Cronin Jr, J. J., M. K. Brady, and G. T. M. Hult. 2000. Assessing the effects of quality, value, and customer satisfaction on consumer behavioral intentions in service environments. Journal of Retailing 76(2), 193-218.

[21] Eggert, A., and W. Ulaga. 2002. Customer perceived value: a substitute for satisfaction in business markets?. Journal of Business and Industrial Marketing 17(2/3), 107-118.

[22] Kuo, Y. F., C. M. Wu, and W. J. Deng. 2009. The relationships among service quality, perceived value, customer satisfaction, and post-purchase intention in mobile valueadded services. Computers in Human Behavior 25(4), 887-896.

[23] Bilgihan, A., F. Okumus, K. Nusair, and M. Bujisic. 2014. Online experiences: flow theory, measuring online customer experience in e-commerce and managerial implications for the lodging industry. Information Technology and Tourism 14(1), 49-71.

[24] Lee, J. S., Lee C. K., and Y. Choi. 2011. Examining the role of emotional and functional values in festival evaluation. Journal of Travel Research 50(6), 685-696.

[25] Zehrer, A., B. Muskat, and M. Muskat. 2014. Services research in tourism: Advocating the integration of the supplier side. Journal of Vacation Marketing 20(4), 353-363.

[26] Morgan, R. M., and S. D. Hunt. 1994. The commitment-trust theory of relationship marketing. The Journal of Marketing, 20-38.

[27] Baker, D. A., and J. L. Crompton. 2000. Quality, satisfaction and behavioral intentions. Annals of Tourism Research 27(3), 785-804.

[28] Dorfman, P. W. 1979. Measurement and meaning of recreation satisfaction: A case study in camping. Environment and Behavior 11(4), 483-510.

[29] Halstead, D., D. Hartman, and S. L. Schmidt. 1994. Multisource effects on the satisfaction formation process. Journal of the Academy of Marketing Science 22(2), 114-129.

[30] Brady, M. K., J. J. Cronin Jr, and R. R. Brand. 2002. Performance-only measurement of service quality: a replication and extension. Journal of Business Research 55(1), 17-31.

[31] Cronin Jr, J. J., and S. A. Taylor. 1992. Measuring service quality: a reexamination and extension. The Journal of Marketing, 55-68.
[32] Oliver, C. 1997. Sustainable competitive advantage: combining institutional and resource-based views. Strategic Management Journal 18(9), 697-713.

[33] Patwary, A. K., and B. Rashid. 2016. The impacts of hospitality services on visit experience and future visit intention of student travelers. International Journal of Business and Technopreneurship 6(8), 107125.

[34] Dimitriades, Z. S. 2006. Customer satisfaction, loyalty and commitment in service organizations: Some evidence from Greece. Management Research News 29(12), 782-800.

[35] Gustafsson, A., M. D. Johnson, and I. Roos. 2005. The effects of customer satisfaction, relationship commitment dimensions, and triggers on customer retention. Journal of Marketing 69(4), 210-218.

[36] Royo-Vela, M., and P. Casamassima. 2011. The influence of belonging to virtual brand communities on consumers' affective commitment, satisfaction and word-ofmouth advertising: The ZARA case. Online Information Review 35(4), 517-542.

[37] Berry, L. L., and A. Parasuraman. 2004. Marketing services: Competing through quality. Simon and Schuster.

[38] Garbarino, E., and M. S. Johnson. 1999. The different roles of satisfaction, trust, and commitment in customer relationships. The Journal of Marketing, 70-87.

[39] Hennig-Thurau, T., K. P. Gwinner, and D. D. Gremler. 2002. Understanding relationship marketing outcomes: an integration of relational benefits and relationship quality. Journal of Service Research 4(3), 230-247.

[40] Fullerton, G. 2003. When does commitment lead to loyalty?. Journal of Service Research 5(4), 333-344.

[41] Harrison-Walker, L. J. 2001. The measurement of word-of-mouth communication and an investigation of service quality and customer commitment as potential antecedents. Journal of Service Research 4(1), 60-75.

[42] Rhoades, L., R. Eisenberger, and S. Armeli. 2001. Affective commitment to the organization: The contribution of perceived organizational support. Journal of Applied Psychology 86(5), 825.

[43] Fullerton, G. 2005. How commitment both enables and undermines marketing 
relationships. European Journal of Marketing 39(11/12), 1372-1388.

[44] Keiningham, T., J. Ball, S. Benoit, H. L. Bruce, A. Buoye, J. Dzenkovska, and M. Zaki. 2017. The interplay of customer experience and commitment. Journal of Services Marketing 31(2), 148-160.

[45] Gruen, T. W., J. O. Summers, and F. Acito. 2000. Relationship marketing activities, commitment, and membership behaviors in professional associations. Journal of Marketing 64(3), 34-49.

[46] Levesque, T., and G. H. McDougall. 1996. Determinants of customer satisfaction in retail banking. International Journal of Bank Marketing 14(7), 12-20.

[47] Pritchard, M. P., M. E. Havitz, and D. R. Howard. 1999. Analyzing the commitmentloyalty link in service contexts. Journal of the Academy of Marketing Science 27(3), 333-348.

[48] Carpenter, J. M., and A. Fairhurst. 2005. Consumer shopping value, satisfaction, and loyalty for retail apparel brands. Journal of Fashion Marketing and Management: An International Journal 9(3), 256-269.

[49] De Matos, C. A., and C. A. V. Rossi. 2008. Word-of-mouth communications in marketing: a meta-analytic review of the antecedents and moderators. Journal of the Academy of Marketing Science 36(4), 578596.

[50] Singh, J., and S. Pandya. 1991. Exploring the effects of consumers' dissatisfaction level on complaint behaviours. European Journal of Marketing 25(9), 7-21.

[51] Buhalis, D., and R. Law. 2008. Progress in information technology and tourism management: 20 years on and 10 years after the Internet - The state of e-Tourism research. Tourism Management 29(4), 609623.

[52] Westbrook, R. A. 1987. Product/ consumption-based affective responses and postpurchase processes. Journal of Marketing Research, 258-270.

[53] Schindler, R. M., and B. Bickart. 2005. Published word of mouth: Referable, consumer-generated information on the Internet. Online Consumer Psychology: Understanding and Influencing Consumer Behavior In The Virtual World 32, 35-61.

[54] Amaro, S., and P. Duarte. 2013. Online travel purchasing: A literature review.
Journal of Travel and Tourism Marketing 30(8), 755-785.

[55] Wang, P. 2015. Exploring the influence of electronic word-of-mouth on tourists' visit intention: A dual process approach. Journal of Systems and Information Technology 17(4), 381-395.

[56] King, R. A., P. Racherla, and V. D. Bush. 2014. What we know and don't know about online word-of-mouth: A review and synthesis of the literature. Journal of Interactive Marketing 28(3), 167-183.

[57] Vermeulen, I. E., and D. Seegers. 2009. Tried and tested: The impact of online hotel reviews on consumer consideration. Tourism Management 30(1), 123-127.

[58] Sotiriadis, M. D., and C. van Zyl. 2013. Electronic word-of-mouth and online reviews in tourism services: the use of twitter by tourists. Electronic Commerce Research 13(1), 103-124.

[59] Sharma, N., and P. G. Patterson. 2000. Switching costs, alternative attractiveness and experience as moderators of relationship commitment in professional, consumer services. International Journal of Service Industry Management 11(5), 470490.

[60] Bradley, G. L., and B. A. Sparks. 2012. Antecedents and consequences of consumer value: A longitudinal study of timeshare owners. Journal of Travel Research 51(2), 191-204.

[61] Kim, L. H., and D. J. Kim. 2017. Achieving relational outcomes in casual dining restaurants through consumer commitment. Current Issues in Tourism 20(2), 178-203. 